\title{
THE RESPONSIBILITY OF THE INTERNAL AUDITOR IN MANAGING THE RISK OF HIV/AIDS
}

\author{
Philna Coetzee
}

Department of Auditing, University of Pretoria

\begin{abstract}
HIV/AIDS is not only a risk to the world population, it is potentially devastating to individual organisations. According to the King Report on Corporate Governance, as well as other governance reports world-wide, risk management is primarily the responsibility of the board and senior management. The internal auditor however, has a responsibility to assist management with this task. This paper aims to determine whether internal auditors are aware of the potential threat that HIV/AIDS holds for their organisations. If ignorance is found to be widespread, recommendations are made to the Institute of Internal Auditors to make their members aware. If awareness is found to be adequate, the paper aims to determine whether internal auditing departments in various sectors of the South African business community are complying with this responsibility.
\end{abstract}

JEL M14

\section{1}

\section{Introduction}

Although the internal auditing profession is not new in the business environment, it has undergone major changes over the last few years (Krogstad, Ridley \& Rittenberg, 1999: 27; Dittenhofer, 2001: 458). Internal auditors not only act as the right hand of management in ensuring that policies, plans and procedures are adhered to, but now also, according to the new definition of internal auditing, play a consulting role, investigating and reporting on crucial issues such as the business risks threatening the organisation (Krogstad et al., 1999: 27).

One of the main risks threatening the world population in general, but the business environment in particular, is the disease called HIV/AIDS (UNAIDS, 2000). The extent to which this disease will affect the business environment and individual organisations is somewhat uncertain. Responding to HIV/AIDS in the workplace is essentially about managing the disease and the issues surrounding it. This implies having accurate and relevant information about the disease, monitoring its progress, knowing or predicting the risk to the organisation, and addressing the risk by managing it (Evian, 1998: 4).

Various studies have indicated that the management of many organisations are aware of the risk posed by HIV/AIDS to these organisations (UNAIDS, 2000; Barac \& Otter, 2001; Deloitte \& Touche, 2002; Randall, 2002; Barnett \& Whiteside, 2002). However, it is still uncertain whether internal auditors are supporting management in a consulting capacity in the monitoring and management of HIV/ AIDS, by studying the effect of HIV/AIDS on organisations. No formal research has been conducted to date on the role of the internal auditing function in managing the potential threat of HIV/AIDS to organisations, particularly the achievement of organisational objectives. According to Performance Standard 2100 of the Professional Practice Framework of the internal auditing profession, internal auditors should assist their organisation by identifying and evaluating significant exposure to risk (Institute of Internal Auditors, 2003). The question arises whether internal auditors, in an assurance or consulting capacity, are aware of their professional responsibility 
regarding the effect of HIV/AIDS as a risk or potential risk to organisations. If not, should they be informed? If internal auditors are in general aware of the problem, what are they doing about it, and is this action sufficient to supply management with information they need to address this risk?

This study aims to determine whether internal auditors are currently playing a role in the managing of the risk of HIV/AIDS in organisations, and what this role is or should be according to the corporate governance responsibilities of internal auditors. The study will focus on internal audit functions in South Africa, but as internal auditing is a global profession, the results will be applicable for internal auditors world-wide. The results can be used to develop guidelines for internal auditors to assist them in managing this risk.

\section{2}

\section{Background of the study}

To appreciate the potential role of internal auditors in managing the risk HIV/AIDS poses to organisations, it is first necessary to understand the internal auditing profession and the role of internal auditors in risk management and corporate governance. Thereafter, the disease HIV/AIDS must be discussed to underline the potential threat of HIV/AIDS to organisations, and in particular the business environment.

\subsection{The internal auditing profession}

As early as the beginning of the twentieth century, economic growth made it difficult for organisations to maintain control of business activities and operational efficiency (Sawyer, Dittenhofer \& Scheiner, 1996: 9; Institute of Internal Auditors, 2003; Ramamoorti, 2003: 3-4). Management lost direct contact with most of its subordinates. To overcome the problem of controlling the organisation's many activities, people known as internal auditors were appointed to review and report on what was happening. The tasks performed by the internal auditors varied from checking routine financial and operational activities, to analysing and appraising these activities (Institute of Internal Auditors, 2003).

As the profession evolved, internal auditors wanted greater recognition of their function and, on 17 November 1941, The Institute of Internal Auditors (IIA) was established in the United States of America (Institute of Internal Auditors, 2003). The initial purpose of the IIA was to provide internal auditors with an opportunity to share their common interests and concerns (Sawyer et al., 1996: 9). Today the IIA is an international organisation that meets the needs of 103000 members in 160 countries and is dedicated to the continuing professional development of individual internal auditors and the internal auditing profession as a whole (Institute of Internal Auditors, 2005).

In 1944, Arthur E Hald, one of the founders of the IIA, made the following statement: "Necessity created internal auditing and is making it an integral part of modern business. No large business can escape it. If they haven't got it now, they will have to have it sooner or later, and, if events keep developing as they do at present, they will have to have it sooner" (Flesher, 1996:3). The truth of these words has become apparent, since internal auditing has been recognised as one of the fastest growing professions of the second half of the twentieth century (Flesher, 1996: 3; Moeller, 2005: 4-5). The role of internal auditing has expanded from that of watchdog (performing assurance activities for management) to that of guide dog for management (Krogstad et al., 1999: 28). The responsibilities of modern internal auditing are as broad as the current business environment it operates in. Internal auditors need to add value to an organisation by making sure that that organisation's activities are performed economically, efficiently and effectively. They must also identify potential as well as existing risks that threaten the organisation as a whole by addressing corporate governance in their audit activities and by making sure that the organisation keeps up with the latest technology and processes (Krogstad et al., 1999; Marks, 2001: 45; Nagy \& Cenker, 2002: 131, 134; Hermanson \& Rittenberg, 2003: 32).

To make sure that internal auditors keep up with changes in their environments, the IIA 
developed a Common Body of Knowledge (CBOK) in 1972 (Institute of Internal Auditors, 1992; Sawyer et al., 1996: 29). This has been regularly updated, and in 1999 the IIA's Research Foundation developed the Competency Framework for Internal Auditors (CFIA), to provide internal auditors with guidelines as to the knowledge and competencies needed to stay up-to-date with the changing business environment (McIntosh, 1999: 5).

In the early years of the internal auditing profession, the environment in which internal auditors tended to operate in, namely internal auditing departments or activities, lacked guidance on the role and responsibility of auditors towards the organisation they served (Sawyer et al., 1996: 30). According to Mautz and Sharaf (1984: 11), contemporary records show that internal auditing was a wellestablished and well-respected activity, but there is little indication that it was well defined or clearly directed. A Statement of Responsibilities of Internal Auditing was prepared by the research committee of the IIA and approved by the Board of Directors at its meeting on 15 July 1947 (Institute of Internal Auditors, 2003). The purpose of the Statement was to establish a set of guidelines that defined the proper role and responsibilities of the internal auditing function within an organisation (Flesher, 1996: 34; Sawyer et al., 1996: 20-24). The Statement has been regularly updated since its first publication, and in June 1999, the IIA's Board of Directors voted and approved a new set of guidelines, headed by a new definition, in the form of the Professional Practice Framework (Institute of Internal Auditors, 2003).

The new definition was approved on 26 June 1999 by the IIA Board of Directors (Krogstad et al., 1999: 27): The definition is not only the starting point for these new guidelines, but forms the basis for the Professional Practice Framework (PPF) (Krogstad et al., 1999; Institute of Internal Auditors, 2003). The definition reads as follows: "Internal auditing is an independent, objective assurance and consulting activity designed to add value and improve an organisation's operations. It helps an organisation accomplish its objectives by bringing a systematic, disciplined approach to evaluate and improve the effectiveness of risk management, control and governance processes." This definition highlights the consulting role of an internal auditor, as well as the fact that this role is based on the assistance internal auditors can offer to management in accomplishing the organisation's objectives, particularly in governance, by identifying and managing threats (risk management), including HIV/AIDS. The new definition underlines the wider responsibilities of internal auditors and therefore necessitated a revision of the guidelines embodied in the PPF.

The Standards for the Professional Practice of Internal Auditing (hereafter referred to as the Standards), as one form of the guidelines provided by the PPF, are the minimum requirements of acceptable practice to be maintained by internal auditors within the profession. The Standards consist of various criteria by which the activities of internal auditing can be evaluated and measured (Institute of Internal Auditors, 2003). The Standards have been restructured to align them with the new definition of internal auditing and now have a much broader perspective, prescribing a proactive role for internal auditors, not only in control activities, but also in risk management and corporate governance processes.

\subsection{The role of internal auditing with respect to risk management and corporate governance}

As can be seen from the new definition of internal auditing, internal auditors are expected to add value and justify their existence by advising management in matters of control, risk and corporate governance processes and the factors threatening these (Marks, 2001: 45). Therefore, if HIV/AIDS threatens the accomplishment of the organisation's objectives, internal auditors should investigate the effect of this risk on the organisation and play a consulting role in adding value to the organisation and assisting management in dealing with this problem. 
In South Africa, the King Committee on Corporate Governance has investigated corporate governance to promote the highest standards in business management (King Committee on Corporate Governance, 2002: $8)$. The King Report II concludes that the objective of internal auditing is to assist management in the effective discharge of its duties and responsibilities. Although the report emphasises that the implementation of risk management, control and corporate governance are the responsibility of the Board and management, it recognises the role of the internal auditor by incorporating the Standards of the IIA regarding these issues into its guidelines (King Committee on Corporate Governance, 2002: 76, 88). The role of internal auditing in risk management and corporate governance will now be briefly discussed.

\subsubsection{Risk management}

The general concept of risk is an everyday phenomenon, both in the business world and in numerous professional and academic disciplines. According to various dictionaries and other relevant literature (Skipper, 1998: 6; Valsamakis, Vivian \& Du Toit, 2000: 29-30; Pickford, 2001: 25), risk is the possibility that an accident or a loss could occur, or that there is a threat as a result of an uncertainty. Business risk is classified as uncertain future events that could affect the organisation, preventing it from reaching its objectives (PricewaterhouseCoopers, 1999: 6; King Committee on Corporate Governance, 2002: 73). This definition links risk to three key elements, namely:

- Uncertainty: Risks are uncertain future events that could influence the achievement of the organisation's strategic, operational and financial objectives;

- Loss of opportunity: Risks embody the possibility that an opportunity to achieve something positive could be lost; and

- Hazard: Risks embody the possibility that an action has a potentially negative outcome.

(PricewaterhouseCoopers, 1999: 6-7; King Committee on Corporate Governance, 2002:
73-74; Chapman, 2003; Kinney, 2003; COSO Report, 2004: 13-16).

The process of identifying and analysing risk is ongoing. As the organisation's circumstances both internal and external change, the resultant risks threatening the objectives should be addressed (COSO, 1992). To manage all the diverse risks facing the organisation, a structured approach is required. Management should have an understanding of the concept of risk in general, of the specific risks that threaten the organisation and of the risk management process (King Committee on Corporate Governance, 2002; Chapman, 2003: 30; Spira \& Page, 2003: 642). Furthermore, according to the IIA's Performance Standard 2110, the internal auditing activity should assist the organisation by identifying and evaluating significant exposures to risk (Institute of Internal Auditors, 2003).

The COSO Report: Enterprise Risk Management (COSO, 2004) was published in September 2004. This document focuses on risks management for the business environment, and advocates the use of controls as tools to assist in managing the risks threatening an organisation. Therefore, management must understand risks in general to be able to identify threats to the organisation and its objectives, and to implement a suitable risk-management programme to address and minimise these threats. In turn, internal auditors need to understand the governance processes implemented by management to be able to play a consulting role in the management of the organisation, including the management of risks.

\subsubsection{Corporate governance}

According to Fama and Jensen (1983: 311), corporate governance is defined as "the range of control mechanisms that protect and enhance the interest of shareholders of business enterprises". Management is about running a business and corporate governance is about seeing that it is run properly (Tricker, 1984: 1).

More than ever before, management and audit committees are seeking assistance from internal auditors on corporate governance issues 
(Steinberg \& Pojunis, 2000: 34; Colbert, 2002: 148). This need was also recognised when the concept of corporate governance was incorporated into the new definition and the Standards of internal auditing (Institute of Internal Auditors, 1999), as well as the King Report (King Committee on Corporate Governance, 2002: 73-81).

As the role of internal auditing evolved to include increased guidance, it became necessary to identify specific areas where the internal auditing activity could assist management (Steinberg \& Pojunis, 2000: 36). The IIA's Performance Standard 2130 states that the internal auditing activity should contribute to the organisation's governance process by evaluating and improving that process (Institute of Internal Auditors, 2003). The IIA Research Foundation and PricewaterhouseCoopers have conducted a study of the Board of Directors' responsibilities and leadership role, and have identified the tools that internal auditors need if they are to assist management (PricewaterhouseCoopers, 2000: 2). This study identifies eight key responsibilities of the Board, including risk management, and agrees that risk is one of the five areas where internal auditors should assist management.

With the exception of strategy, the topic discussed most at Board level is risk (Steinberg \& Pojunis, 2000: 36; IFAC, 2004: 47-48; Bhimari \& Soonawalla, 2005: 166). Directors do not like surprises that could threaten the achievement of their organisation's objectives and goals. Because managing risk is a core competency for most internal auditing departments, the department can provide great value by helping the Board to identify significant risks (Colbert, 2002: 149). Management tends not to ensure that the organisation has an effective, ongoing process to identify risks. It also tends not to measure the potential impact of a varied set of assumptions, nor does it do what is necessary to manage risks proactively (Steinberg \& Pojunis, 2000: 37; IFAC, 2004: 32).

As this discussion of the new definition of internal auditing and the references made to the PPF and CFIA have made clear, internal auditors in a consulting capacity are well equipped to assist management in identifying the effect of risks on an organisation. It is also clear that internal auditors can be expected to assist management in the areas of control and risk, and therefore to deliver value at the highest levels of their organisation by enhancing good corporate governance.

The question to be answered now by management and internal auditors is whether or not HIV/AIDS is a risk, not only globally or to individual countries or areas, but also to specific communities and organisations functioning within specific boundaries.

\subsection{The disease HIV/AIDS}

HIV/AIDS is a known threat to the world, especially sub-Saharan Africa and South Africa (UNAIDS/WHO, 2003). It is vital that the consequences of the disease on economies, and governments, and on the business environment and individual organisations in particular, are studied. Studies performed inter alia by the Centre for International Health, Boston University School for Public Health (2002), Barac and Otter (2001), SABCOHA (2002), Deloitte\&Touche (2002), and others indicate that management is often aware of the possible risk posed by HIV/AIDS to their organisations.

To determine the effect of HIV/AIDS on the business environment and on the organisation, internal auditors need to familiarise themselves with how the virus works. The human immunodeficiency virus (HIV) enters the body, and attacks the immune system. The immune system's function is to control or eliminate viruses that threaten the body, and to eliminate damaged body cells that could become cancerous. If the immune system deteriorates, the body cannot fight diseases and becomes ill. When illnesses of any kind, from influenza to cancer, together with HIV, attack the immune system, this is known as the acquired immune deficiency syndrome (AIDS). The result of AIDS is death (Ward, 1999: 386, Barnett \& Whiteside, 2002: 34). Unfortunately knowing that HIV causes AIDS and thus ultimately causes death is only the beginning of understanding the disease. 
Today two types of HIV are known, namely HIV-1 and HIV-2. They are very similar, but HIV-1 is more aggressive in causing diseases. Apart from this difference in the viruses, scientists have now identified 11 subtypes of the HIV-1 virus (Ward, 1999, Janse van Rensburg, 2000: 267). The study and tracking of each subtype is important, as each type responds differently to a given treatment. Reinfection by another type of HIV-1 virus can damage the immune system of a person already infected with an HIV-1 virus even more rapidly than infection by only one type. The effect of re-infection of individuals on an organisation can thus be catastrophic, as people who are infected with different subtypes become weaker more quickly and die faster.

Knowing how long a person has between infection and illness, with subsequent death, is important for plotting the effect of the epidemic on the economy and society. The period from HIV infection to death varies, depending on the individual's circumstances. It has long been believed that with a healthy lifestyle (proper medical care, nutritious food, a stress-free life and non-exposure to infections), the period from initial infection by HIV to the development of AIDS averages ten years, and with proper treatment, including prescribed drugs, from the onset of AIDS to death, two years. However, recent studies indicate that resistance to existing drugs is growing (Barnett $\&$ Whiteside, 2002: 44). The virus continues to mutate. Today, in addition to the subtypes, there are over 120 sites of variation in the virus's structure. Hence, the incubation period has shortened to an average of seven years (Barnett \& Whiteside, 2002: 44).

All epidemics have a specific pattern. First, infection of the population proceeds slowly, with some affected and others missed. Then infection increases dramatically. Lastly, the number of new infection slows down as most people are already infected and the epidemic reaches a plateau (Barnett \& Whiteside, 2002: 46). What makes HIV/AIDS different from other epidemics is the fact that there are two curves (see Figure 1), namely one for HIV and one for AIDS (Barnett \& Whiteside, 2002: 47-48). This dual pattern makes this disease very dangerous, as people tend to forget about the second curve that follows a few years after the first.

Figure 1

The two epidemic curves of HIV/AIDS

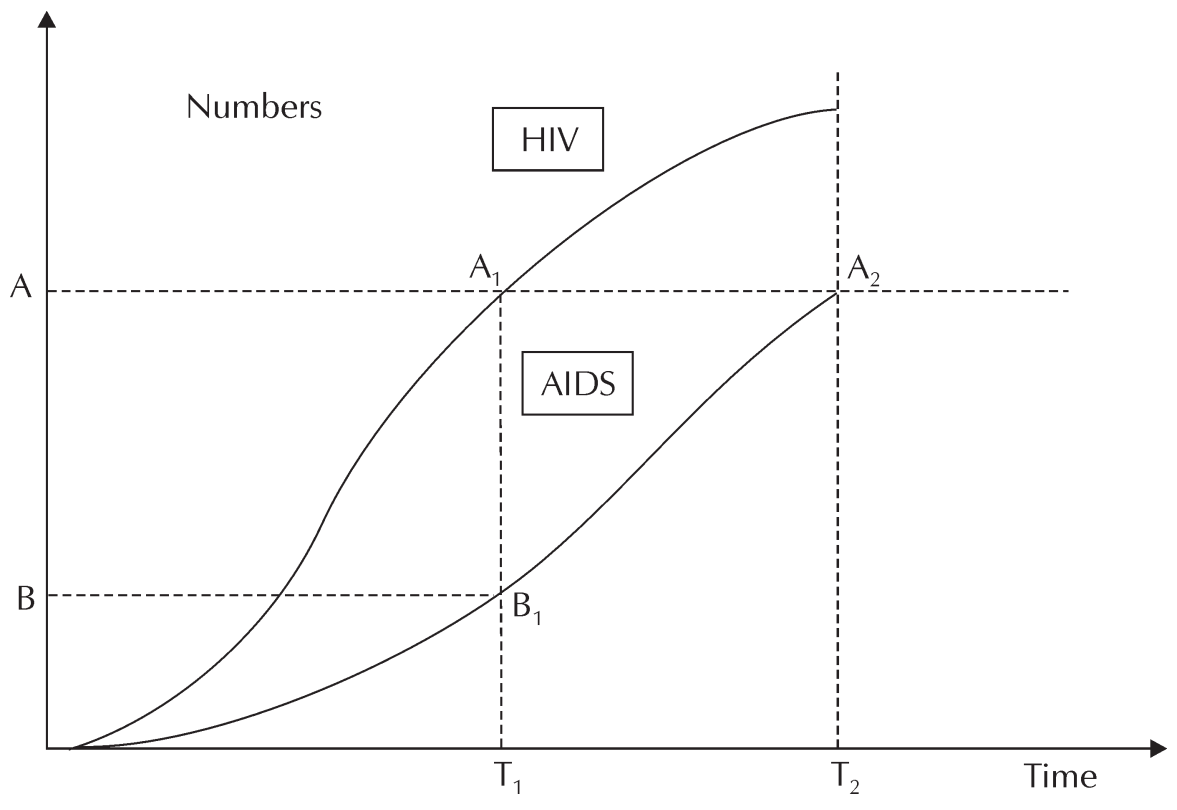

Source: Barnett \& Whiteside (2002: 48) 
At a given time $\left(\mathrm{T}_{1}\right)$, the number of people infected with HIV $\left(\mathrm{A}_{1}\right)$ does not dramatically influence the community or workforce, as some of them will not even know they are infected or will not become ill, and the number of AIDS cases $\left(\mathrm{B}_{1}\right)$ is low. People tend to forget that all people with HIV $\left(\mathrm{A}_{1}\right)$ will get $\operatorname{AIDS}\left(\mathrm{A}_{2}\right)$ and will die. It is important for management to determine what the HIV rate is at a given time for their organisation, as this will not only help management to determine the effect of the disease on the organisation at that time, but also give an indication of the risk to follow (that is, the number of AIDS cases).

The United Nations' programme on HIV/ AIDS, known as UNAIDS, joined forces with the World Health Organisation (WHO) to address this problem globally. Various studies by these organisations and information received from different countries are published on a regular basis (UNAIDS/WHO, 2004), the latest being the UNAIDS/WHO report issued in December 2004. This report states that, globally in 2004, AIDS is estimated to have claimed more than 3 million lives and 5 million people to have been newly infected with HIV, bringing the total number of people living with the virus to an estimated 40 million (UNAIDS/WHO, 2004).

Globally, sub-Saharan Africa is the most severely affected region, with the Southern African Development Community containing the highest number of infected individuals (UNAIDS/WHO, 2004). In South Africa, the Department of Health annually performs a HIV/AIDS study by testing all pregnant women attending a public sector antenatal clinic (Department of Health, 2001: 1). This is not the most accurate method of determining the national HIV/AIDS prevalence rate, as abortions are not included. Also, a woman who is HIV-positive has a 50 per cent less chance of becoming pregnant than one who is HIVnegative (Barnett \& Whiteside, 2002: 19), woman are more likely to be infected than men (Ward, 1999: 216) and not all pregnant women necessarily attend public sector clinics, making the method even more problematic. The government has declared HIV/AIDS a nonnotifiable disease (Department of Health, 1997:
33). Therefore estimating the extent of the disease in South Africa is difficult.

Currently HIV/AIDS cases in South Africa are estimated at approximately 30 per cent of the population (UNAIDS/WHO, 2004). Infection levels are very high amongst young, economically active persons (SABCOHA, 2002: 15; Department of Health, 2003: 5; UNAIDS/WHO, 2004). This indicates that HIV/AIDS will have an overwhelming effect on the current and potential workforce as the youth is our future and, therefore, the HIV/ AIDS amongst the youth is a great threat to achieving strategic business objectives and a great business risk for individual organisations.

\subsection{The effect of HIV/AIDS on the business environment}

The most obvious impact of HIV/AIDS on the business environment is its effect on the labour force, as the discussion above suggests. Principally, the disease affects people during their most productive years of life (Department of Health, 2001: 7). As labour is a key input in production, lower growth in the population and thus in the workforce will have a negative effect on economic growth (SABCOHA, 2002: 15). It is therefore important for governments, the business environment and in particular the management of organisations to be aware of HIV/AIDS as a potential business risk.

The effect of HIV/AIDS on organisations can be divided into two main groups, namely risks threatening the external environment and those influencing the internal environment. Internal risks can further be divided into direct and indirect risks. External risks include, for example (Randall, 2002: 88-89):

- economic risks (decrease in Gross Domestic Product growth, increase in inflation as a result of increased labour cost);

- market risks (decrease in demand as a result of a drop in the number of consumers);

- service delivery failure;

- collapse of business partners' operations; and

- political or legislative risks (various laws that influence business operations). 
Statistics issued by major companies confirm that these risks are real. One such example is the decline in beer production in South Africa. According to News 24 (Stoddard, 2002), South African Breweries (SAB) must expand their market globally as its domestic market is literally dying. A study conducted by the company in 2002 projected that 12,58 million fewer litres of beer would be sold during 2002 as a result of AIDS, declining to 41,68 million fewer litres in 2006.

Risks influencing the internal environment can either be caused directly by death, absenteeism or illness, or indirectly. Direct risks include (Randall, 2002: 88-89):

- increased cost of group life cover;

- cost of providing medical and retirement benefits;

- cost of absenteeism;

- higher staff turnover (cost for recruitment and training new staff);

- cost of compassionate leave (attending funerals or attending to sick family members) or sick leave (providing additional parttime employees to do the job);

- cost of HIV/AIDS management programmes (including consultant's fees); and

- increased cost of bad debts as a credit risk.

Statistics underlying these risks have been released by various companies. Examples include increased production costs for the gold mine group Gold Fields Limited of about US\$6 per ounce. The cost to the company as a result of the disease for Anglo Platinum was R75 million for 2002 (Bain, 2002: 17). One of South Africa's biggest employers, Eskom, spends R180 million annually on an HIV/AIDS programme (Isa, 2002), and according to a study done by the Minister of Public Service and Administration in 2000, AIDS is officially the biggest killer of public servants (Anonymous, 2002).

Other risks consequent upon direct risk are often difficult to quantify. This does not mean, however, that they are less serious or should be ignored. Such indirect risks include (Randall, 2002: 88-89):
- reductions in staff productivity (as a result of illness);

- increase in staff supervision;

- influence on competency levels (high staff turnover);

- increased litigation (many laws and regulations regarding treatment of employees with HIV/AIDS);

- higher salaries (the loss of skilled or managerial competencies);

- loss of workforce morale (people without HIV/AIDS feel that they have to work harder);

- loss of client relationship (due to high staff turnover); and

- decline in reputation in the business environment or clients (result of bad service).

This list is not exhaustive, but it gives an indication not only of the scope of possible risks, but also of the fact that HIV/AIDS is a risk to any organisation that has customers and/or employees. The only way for organisations to address this risk is to implement a proper riskmanagement strategy. Some of these risks are easy to quantify (for example, with the help of actuarial models), whilst others are more difficult. The King Report II on Corporate Governance states as one of its recommendations for sound corporate governance that companies should understand the social and economic impact that HIV/AIDS will have on business activities; adopt an appropriate strategy, plan and policy to address and manage the impact; regularly monitor performance; and report on HIV/AIDS to stakeholders (King Report on Corporate Governance, 2002: 117). This clearly shows that it is essential for organisations not only to have a proper plan in place, but also to report to stakeholders on this plan, as well as on the effect of HIV/AIDS on the organisation.

From a study performed by Deloitte\&Touche (2002: 5) involving 110 South African companies, it is clear that while most larger companies (with more than 500 employees) do have a formal policy, they still tend to 
underestimate the effect that HIV/AIDS will have on their organisations. The study indicates that only 27,3 per cent of the respondents in the survey have commissioned a risk assessment to assess their current and future HIV/AIDS risk. This lack of foresight is probably the result of companies not performing anonymous prevalence tests (only 11 indicate that either anonymous blood or saliva tests have been performed), which means that they do not know the percentage of their employees that are HIVpositive. Management can only know the true effect of the disease and how this should be managed in their organisation after an anonymous in-house prevalence study has been conducted (SABCOHA, 2002: 15). Such studies allow management to gauge the actual risk threatening the organisation and to judge whether they need expert assistance in managing the risk.

\section{3}

\section{Literature study}

A search of the relevant literature and information resources such as libraries and the Internet establishes that no formal research has been conducted to date on the role of the internal auditing function in the management of the potential risk of HIV/AIDS to business organisations in South Africa. Relevant literature on related topics has therefore been consulted in an effort to establish what the professional responsibility of internal auditors should be regarding risk management, with specific reference to HIV/AIDS.

The Institute of Internal Auditors Research Foundation has conducted various studies (Miccolis, Hively \& Merkley, 2001: 35; Walker, Shenkir \& Barton, 2002: 2) on enterprise risk. Managing risk means aligning resources (for example, people, technology and knowledge), business strategy and processes to manage the uncertainties that an organisation faces. Internal auditors have already been made aware that they have an important role to play in risk management. In particular, Performance Standard 2110 suggests that the internal auditing activity should assist management in identifying and evaluating risks (Institute of Internal Auditors, 2003). Therefore, we can conclude that the internal auditing profession is generally aware of its professional responsibility regarding the management of risk.

The discussion above showed that HIV/AIDS is a threat to the world, countries, governments, society and individuals. Statistics indicate that certain countries, communities, age groups, organisations, business sectors, and so on will be more severely affected by this disease than others (Barnett \& Whiteside, 2002). Internal auditors thus have to investigate the effects of HIV/AIDS on the specific organisation to be able to identify whether this disease is an enterprise risk or not, or suggest such an investigation to management. Although research has been conducted by the IIA Research Foundation on the risk that people posed to an organisation (Miccolis et al., 2001: 33), no formal proof is available to suggest that investigation of the effects of HIV/AIDS by internal auditing is currently standard practice in organisations. This issue is therefore investigated further in this study, by means of interviews with chief audit executives, that is, heads of internal auditing departments or activities in various organisations in South Africa.

\section{4}

\section{Research methodology}

A survey (Abdel-Khalik \& Ajinka, 1979: 45) was conducted among chief audit executives (or an individual internal auditor with the most knowledge of HIV/AIDS identified by the chief audit executive) of various organisations' internal auditing functions to study their views on the role of internal auditing in managing the risk of HIV/AIDS. This research method can be described as a fact-finding and hypothesisgenerating process, according to which data is collected in a planned manner to discover the incidence, distribution and interrelation of certain variables. The data is commonly collected by means of personal interviews, mail questionnaires or telephone questionnaires and usually relates to facts, opinions, beliefs, 
attitudes or behaviour (Abdel-Khalik \& Ajinka, 1979: 45; Zikmund, 2000: 190). In view of the dearth of knowledge on the role of internal auditors in managing the potential risk of HIV/ AIDS to an organisation, as well as the sensitivity of the subject, it was decided that this research method will make the best positive contribution, provided it can establish authoritative viewpoints. The study therefore focuses on the perceptions of chief audit executives on the role of the internal auditor in managing the potential risk of HIV/AIDS to an organisation. Similarities and differences between the perceptions of the interviewees are expected to further enhance understanding of and give interesting insights into the various issues concerned. These results may also provide justification for recommendations to be made to the IIA so that it can provide appropriate guidance to its members.

A formal questionnaire was designed, set and used during the interviews to eliminate biases inherent in the design and wording of the questions asked. With the help of the Institute of Internal Auditors in South Africa, two groups of chief audit executives were chosen, namely some from larger organisations with more than 10000 employees, and some from smaller organisations with fewer than 10000 employees. Results obtained from the chief audit executives of internal auditing departments that have a sound relationship with the national governing body of internal auditors in South Africa are assumed to be fairly safe to generalise, extrapolating them to the rest of the internal auditing functions that have a link to the national Institute.

The reason for the distinction made between larger and smaller organisations is that the internal auditing functions at smaller organisations, although functionally the same as those at larger organisations, could differ in several respects, since fewer funds are often made available for internal auditing activities in smaller organisations. If this is true, smaller organisations will also probably spend less on managing the potential risk of HIV/AIDS. This distinction was included in the study to ensure that any results obtained would be reliable for all organisations, large or small.

For the larger organisations, the following sectors were included in the sample population:

- services;

- mining;

- finance;

- petroleum industry; and

- retail.

For the smaller organisations, the following sectors were included:

- telecommunications;

- services;

- construction;

- production; and

- finance.

Statistical sampling was not applied in the study, for the simple reason that not all organisations have internal auditing departments. Also, not all internal auditing departments function at their full potential because internal auditing is a relatively new profession in the South African business environment. With the issuing of the King Report II (King Report on Corporate Governance, 2002) and the Public Finance Management Act, Act No 1 of 1999 as amended, a number of internal auditing functions are only in the process of either being established or of being upgraded in many South African organisations. The list of people attending the Institute of Internal Auditor's Annual Conference during August 2003 was used as a basis for determining which sectors should be targeted. It should be noted that the public sector is not part of the investigation.

The information gathered from the interviews was summarised after each interview. After all the interviews had been completed, a spreadsheet was compiled to compare the responses of all the interviewees to each question. The results of this data-gathering process, as well as an interpretation of the results, is presented and discussed in section 6 . 


\section{5 \\ Limitations of the study}

Although great care was taken in obtaining accurate and useful information, this research study has certain limitations. The research method used has certain shortcomings that should be noted, especially when the conclusions drawn from the analysis of the data are considered (Buckley, Buckley \& Chiang, 1976: 44; Oppenheim, 1992: 21; Emory, 1985: 158; Zikmund, 2000: 196). These shortcomings include, firstly, the fact that opinions are not factual but only present the impressions of the respondents. Secondly, the strategy has certain methodological shortcomings, such as biases inherent to the design and the wording of the questionnaire (the researcher sets the questions, determines the target and determines the time of the research), systematic biases where the target tends to focus on favourable or strong statements, and systematic biases in the administration of the questionnaire. Thirdly, the quality and accuracy of the information gathered will depend on the ability and willingness of the target to co-operate. Lastly, errors can occur in the preparation, interpretation and analysis of the data and the results can be wrongly interpreted.

As previously mentioned, HIV/AIDS is a relatively new potential risk to organisations world-wide as well as in South Africa, and therefore the implications for the internal auditing discipline are somewhat unclear. Knowledge of the disease is limited, as even medical experts are uncertain about all the issues related to HIV/AIDS. This is underlined by much current research on the medical aspects of the disease. HIV/AIDS is also a very sensitive issue, complicated by the government's decision to keep it a non-notifiable disease and by the great stigma currently attached to the disease. People fear the disease and do not like to talk about its existence. These problems could skew the results of this study.

Lastly, no similar studies have been conducted, so the questionnaire had to be designed from first principles and may therefore be incomplete. With all these limitations in mind, the results of the survey conducted can now be discussed.

\section{Discussion of the results of the personal interviews}

The knowledge of each chief audit executive in each organisation about HIV/AIDS had first of all to be established. All interviewees indicate that they believe HIV/AIDS is a threat to their organisations. They even know where this risk lies on their organisation's risk ranking list, situating it at high risk. All agree that the internal auditing activity advises management on various risk matters and all indicate that this should include the risk of HIV/AIDS.

To the question: "What do you think is or should be the role of internal auditing regarding this risk / potential risk of HIV/AIDS?" the following answers were received:

\begin{tabular}{|l|c|c|}
\cline { 2 - 3 } \multicolumn{1}{c|}{} & $\begin{array}{c}\text { Small } \\
\text { organisations }\end{array}$ & $\begin{array}{c}\text { Large } \\
\text { organisations }\end{array}$ \\
\hline No role & $20 \%$ & - \\
\hline Treated as other risks & $80 \%$ & $100 \%$ \\
\hline
\end{tabular}

Comments vary, with some respondents saying that the internal auditing function need take only a consulting role (giving advice to management and making sure management has a policy in place), and others insisting on a more active role in managing the risk (assuring that the risk is managed by performing audits on the policies, strategies and plans of management; facilitating workshops; monitoring management's actions; and incorporating HIV/AIDS issues in the human resources audit).

These finding are however contradicted by the answers received to a number of specific questions focussing on what the internal auditing department's tasks are in managing this risk. Only major issues were included in the interviews, such as:

- monitoring of HIV/AIDS;

- formal policy;

- legislation;

- prevalence studies; and 
- monitoring the effects and the cost of HIV/ AIDS.

When asked: "Is internal auditing actively involved with the monitoring and managing of HIV/AIDS?" respondents gave the following responses:

\begin{tabular}{|l|c|c|}
\cline { 2 - 3 } \multicolumn{1}{c|}{} & $\begin{array}{c}\text { Small } \\
\text { organisations }\end{array}$ & $\begin{array}{c}\text { Large } \\
\text { organisations }\end{array}$ \\
\hline Not involved & $60 \%$ & $67 \%$ \\
\hline $\begin{array}{l}\text { Involved via } \\
\text { committees }\end{array}$ & $20 \%$ & $17 \%$ \\
\hline Monitoring & $20 \%$ & $17 \%(*)$ \\
\hline
\end{tabular}

$(*)$ Only as part of Human Resources audit

To the questions: "Does your company have a HIV/AIDS policy?" and "What is the role of internal auditing regarding this policy?", all respondents reply that their organisations have a formal policy in place. The role of the internal auditing activity is confirmed as being:

\begin{tabular}{|l|c|c|}
\cline { 2 - 3 } \multicolumn{1}{c|}{} & $\begin{array}{c}\text { Small } \\
\text { organisations }\end{array}$ & $\begin{array}{c}\text { Large } \\
\text { organisations }\end{array}$ \\
\hline Part of the process & $40 \%$ & $33 \%$ \\
\hline Part of development & $20 \%$ & $0 \%$ \\
\hline
\end{tabular}

Regarding the additional legislation that organisations must adhere to as a result of HIV/ AIDS, to the question: "Are you aware of all the relevant legislation regarding HIV/AIDS?" nearly all of the respondents, namely 81.8 per cent, confirm that they are aware of the applicable legislation. When asked: "Is there someone in the organisation monitoring if the company complies with the legislation regarding HIV/AIDS and is internal auditing incorporating this in their audits?", the respondents give the following answers:

\begin{tabular}{|l|c|c|}
\cline { 2 - 3 } \multicolumn{1}{c|}{} & \multicolumn{1}{c|}{$\begin{array}{c}\text { Small } \\
\text { organisations }\end{array}$} & $\begin{array}{c}\text { Large } \\
\text { organisations }\end{array}$ \\
\hline $\begin{array}{l}\text { Monitor by } \\
\text { organisation }\end{array}$ & $100 \%$ & $67 \%$ \\
\hline Incorporate in audits & $0 \%$ & $0 \%$ \\
\hline
\end{tabular}

To the following questions regarding prevalence studies undertaken by the organisation: "Does your company perform prevalence studies?" and "What is the role of internal auditing in the prevalence study(s)?" the respondents gave the following answers:

\begin{tabular}{|l|c|c|}
\cline { 2 - 3 } \multicolumn{1}{c|}{} & \multicolumn{1}{c|}{$\begin{array}{c}\text { Small } \\
\text { organisations }\end{array}$} & $\begin{array}{c}\text { Large } \\
\text { organisations }\end{array}$ \\
\hline $\begin{array}{l}\text { Know what preva- } \\
\text { lence studies are }\end{array}$ & $100 \%$ & $67 \%$ \\
\hline Done by organisation & $60 \%$ & $33 \%$ \\
\hline IA plays a role & $0 \%$ & $0 \%$ \\
\hline
\end{tabular}

A disquieting result is the fact that two of the chief audit executives questioned in the study are unsure about what prevalence studies are and whether these studies are undertaken by their organisations. As indicated above, internal auditing plays no role in these studies; neither in identifying a suitable company or person(s) to perform the tests, monitoring of the process, evaluating the results, assisting management in the interpretation of the information, nor in performing any other part of prevalence studies. When asked: "Does your company monitor the cost of HIV/AIDS?" and "What is the role of internal auditing in this process?", the respondents made the following comments:

\begin{tabular}{|l|c|c|}
\cline { 2 - 3 } \multicolumn{1}{c|}{} & \multicolumn{1}{c|}{$\begin{array}{c}\text { Small } \\
\text { organisations }\end{array}$} & $\begin{array}{c}\text { Large } \\
\text { organisations }\end{array}$ \\
\hline Cost is monitored $\left.{ }^{*}\right)$ & $40 \%$ & $17 \%$ \\
\hline $\begin{array}{l}\text { Uncertain if cost is } \\
\text { monitored }\end{array}$ & $0 \%$ & $33 \%$ \\
\hline IA plays a role & $0 \%$ & $17 \%$ \\
\hline
\end{tabular}

(*) Only certain costs are monitored.

Although the monitoring of the cost of HIV/ AIDS to an organisation is not the task of internal auditors, management must be aware of what this disease is costing the organisation to be able to manage these costs and control the bottom line, namely the profit margin. Internal auditors should make sure that the information management receives is accurate and reliable.

To general questions such as: "Is your internal auditing activity directly affected by HIV/ AIDS?", "Do you think it is essential for internal auditing staff members to have a general knowledge of HIV/AIDS?" and "Is your organisation actively involved with local HIV/ AIDS programmes?", respondents gave the following answers: 


\begin{tabular}{|l|c|c|}
\cline { 2 - 3 } \multicolumn{1}{c|}{} & \multicolumn{1}{c|}{$\begin{array}{c}\text { Small } \\
\text { organisations }\end{array}$} & $\begin{array}{c}\text { Large } \\
\text { organisations }\end{array}$ \\
\hline $\begin{array}{l}\text { IA not affected by } \\
\text { HIV/AIDS }\end{array}$ & $100 \%$ & $50 \%$ \\
\hline $\begin{array}{l}\text { IA should have } \\
\text { general knowledge } \\
\text { of HIV/AIDS }\end{array}$ & $100 \%$ & $100 \%$ \\
\hline $\begin{array}{l}\text { Organisation in- } \\
\text { volved in HIV/AIDS } \\
\text { programmes for } \\
\text { local community }\end{array}$ & $80 \%$ & $83 \%$ \\
\hline
\end{tabular}

Thus although all the respondents agree that HIV/AIDS is a risk to their organisation, their activities and involvement in the managing of this risk varies.

Next, the results of the study will be interpreted so that a logical conclusion may be arrived at and recommendations be made as to how to rectify the problems identified.

\section{7 \\ Summary, conclusions and recommendations}

HIV/AIDS is a risk to the business environment, and internal auditors have a duty to assist management with the monitoring and controlling of risks threatening the organisation and its efforts to meet its objectives. The interviews held with chief audit executives in the internal auditing departments of various South African organisations were structured to investigate these internal auditors' awareness of the potential risk of HIV/AIDS to their organisations and the role of internal auditors in assisting management with handling this risk. Limitations to the methodology include the fact that only eleven chief audit executives were interviewed, that statistical sampling was not used and that the formal questionnaires were not circulated. After completing the personal interviews, the decision not to circulate the questionnaire more widely seems to be the correct one as the interviewees, although eager to participate, were mostly very ignorant about the effect of HIV/AIDS on their organisations. In answering the questions they kept referring to other people in the organisation as doing quite a lot regarding the management of HIV/AIDS. This study's main objective, however, which was to focus on internal auditing's perspective on the risk of HIV/AIDS in South Africa, is still met by the limited results obtained.

The distinction between the smaller and larger organisation was shown to be necessary as, in most cases, the interviewees from smaller organisations prove to be more actively involved or to know more about what their organisations are doing about the risk of HIV/AIDS. It seems that internal auditing in smaller organisations is assisting management on all issues related to risk and compliance. Some of the larger organisations have separate compliance departments, risk management divisions, HIV/ AIDS committees and other forums. In these instances, the chief audit executive often believes that the risk of HIV/AIDS is covered and that internal auditing has a very limited role, if any, to play in the management of HIV/AIDS, which is in contrast to the definition of internal auditing, the Professional Practice Framework of the IIA, especially the Standards, and the King II Report on corporate governance.

The results of the study can be summarised as follows. Interviewees agree that HIV/AIDS is a risk to their organisation and that the internal auditor should advise management on risk matters, including the risk of HIV/AIDS. All indicate that their organisation does have a formalised HIV/AIDS policy, but 54 per cent of the participants indicate that internal auditing departments have not been part of the process of developing or evaluating the final document. Internal auditors are aware of the additional legislation pertaining to HIV/AIDS, but none of the interviewees include these issues in their compliance audits. With regard to prevalence studies performed by management to determine the incidence of the disease amongst the workforce, internal auditing has played no role in assisting management. 18 per cent of the interviewees are even uncertain about what prevalence studies are. The same results are obtained regarding the monitoring of the cost of HIV/AIDS to an organisation. Most interviewees are either unsure whether management is monitoring the cost of the disease, or are sure that it is not. Again, internal auditing plays no 
role in the process by either making management aware of these additional costs, or auditing the process, procedures and methods. Only 9 per cent indicate that their organisation is actively involved in the monitoring of the management and effect of HIV/AIDS, and although these internal auditing activities have been undertaken to address the issues raised in the questionnaire, some are still not properly in place.

The management of risks is the responsibility of the Board of Directors, and the role of internal auditing is to give an assurance to all stakeholders that the risks threatening the organisation are being adequately managed. As discussed in the above paragraph, although all the interviewees agree that HIV/AIDS is a threat to their organisations, only a few are performing their duty regarding this risk. The level of commitment and the tasks performed vary considerably, ranging from total ignorance of HIV/AIDS in a business environment, to having people in the internal auditing department with detailed knowledge of the disease and performing most of the tasks needed to be able to give stakeholders the necessary assurance.

From the discussion outlined above of the roles that management and internal auditing respectively have to play in the management of HIV/AIDS, as well as the summary and results of the study, certain conclusions and recommendations can now be made.

The risk of HIV/AIDS should be managed by the Board of Directors, using expertise available internally or brought in from outside, and aiming either to minimise the effect of the disease on the organisation by controlling certain factors, or to eliminate the risk as far as possible. (Complete elimination of the risk is impossible, since all organisations need people to run them.) The role of internal auditing is limited to giving assurance to all stakeholders that the risk of HIV/AIDS is being adequately managed. Such management should include:

- making management as well as other people aware of the potential threat posed by the disease to the organisation, business unit or department;
- auditing the information used to make decisions regarding HIV/AIDS and compliance with legislation and other rules and procedures;

- auditing workplace programmes on HIV/ AIDS;

- giving advice on and evaluating plans and procedures;

- giving advice on what should be monitored and how this can be done;

- being involved in the implementation of programmes or projects regarding HIV/ AIDS, such as prevalence studies and prevention programmes;

- running the reporting process on HIV/ AIDS including financial statement reporting and sustainability reporting; and

- evaluating the effect on specific areas relevant to the duties of internal auditors such as the control system.

HIV/AIDS is not a common risk; that is, not all people are aware of the real consequences of this deadly disease to the world and its countries, communities, business environments and organisations. Internal auditors may not be specialists in the field of HIV/AIDS, but this does not lessen their responsibility in managing this risk. Internal auditing should treat HIV/ AIDS just like all other risks threatening the organisation. According to the Standards of the IIA, if certain expertise are lacking in an internal auditing function, this expertise must be obtained from elsewhere.

Therefore, this study concludes that internal auditing guidelines should be developed to assist internal auditors in their duty regarding the management of HIV/AIDS. These guidelines should be developed by the IIA, with the help of internal auditors who are actively involved in managing the effects of HIV/AIDS, and also of experts from other areas such as the medical profession, insurance and medical aid organisations, human resource managers and wellness partners. 


\section{References}

1 ABDEL-KHALIK, A.R. \& AJINKYA, B.B. (1979) "Empirical research in accounting: a methodological viewpoint", Accounting Education. 4: 31-46.

2 ANONYMOUS. (2002) "AIDS biggest killer of public servants", News 24. SAPA. http:// www.news24.com. (Accessed 25 June 2002).

3 BAIN, J. (2002) "Big business takes HIV into own hands", Business Day, 8 August: 17.

4 BARAC, K. \& OTTER, J. (2001) "The financial accountability of HIV/AIDS", Meditari Accountancy Research, 9: 1-32.

5 BARNETT, T. \& WHITESIDE, A. (2002) AIDS in the Twenty-First Century: Disease and Globalization, Palgrave-MacMillan: New York.

6 BHIMANI, A. \& SOONAWALLA, K. (2005) "From conformance to performance: The corporate responsibilities continuum", Journal of Accounting and Public Policy, 24(3): 165-174.

7 BUCKLEY, J.W.; BUCKLEY, M.H. \& CHIANG, H.F. (1976) Research Methodology and Business Decisions, National Associations of Accountants: Jersey City, New Jersey.

8 CENTER FOR INTERNATIONAL HEALTH, BOSTON SCHOOL OF PUBLIC HEALTH (2002) The Social and Economic Impact of the AIDS Epidemic, http://www.internationalhealth.org/AIDS_Economics (Accessed 14 November 2002).

9 CHAPMAN, C. (2003) "Bringing ERM into focus”, Internal Auditor, 60(3): 30-35.

10 COLBERT, J.L. (2002) "Corporate governance: Communications from internal and external auditors", Managerial Auditing Journal, 17(3): 147-152.

11 COSO REPORT (COMMITTEE OF SPONSORING ORGANIZATIONS OF THE TREADWAY COMMISSION) (1992) Internal Control - Integrated Framework: Framework, Sponsoring Organizations of the Treadway Commission: Jersey City, New Jersey.

12 COSO REPORT (2004) Enterprise Risk Management Integrated Framework: Executive Summary, Sponsoring Organizations of the Treadway Commission: Jersey City, New Jersey.

13 DELOITTE\&TOUCHE (2002) Evaluation of Workplace Responses to HIVIAids in South Africa - A Rapid Situation Analysis, Deloitte \& Touche Human Capital Corporation, May 2002.

14 DEPARTMENT OF HEALTH (1997) National STD/HIVIAIDS Review: Volume 1. Pretoria: Department of Health.
15 DEPARTMENT OF HEALTH (2001) Summary Report: national HIV and syphilis sero-prevalence survey in South Africa, http://www.doh.gov.za. (Accessed 14 February 2003).

16 DEPARTMENT OF HEALTH (2003) Summary report: National HIV and Syphilis ZeroPrevalence Survey in South Africa, http:// www.doh.gov.za. (Accessed 9 January 2004).

17 DITTENHOFER, M. (2001) "Reengineering the internal auditing organization”, Managerial Auditing Journal, 16(8): 458-468.

18 EMORY, C.W. (1985) Business Research Methods ( $3^{\text {rd }}$ ed.) Irwin: Homewood, Illinois.

19 EVIAN, C. (1998) AIDS Management and Support, Speech presented to the Institute of Internal Auditors Annual Conference in South Africa, June 1998.

20 FAMA, E. \& JENSEN, M. (1983) "Separation of ownership and control", Journal of Law and Economics, 26: 301-325.

21 FLESHER, D.L. (1996) Internal Auditing Standards and Practices, Institute of Internal Auditors: Altemonte Springs: Florida.

22 HERMANSON, D.R. \& RITTENBERG, L.E. (2003) Research Opportunities in Internal Auditing - Internal Audit and Organizational Governance, The Institute of Internal Auditors Research Foundation: Altamonte Springs, Florida.

23 INSTITUTE OF INTERNAL AUDITORS (1992) A Common Body of Knowledge for the Practice of Internal Auditing, Institute of Internal Auditors: Altamonte Springs, Florida.

24 INSTITUTE OF INTERNAL AUDITORS (1999) A Vision for the Future: Professional Practices Framework for Internal Auditing, Institute of Internal Auditors: Altamonte Springs, Florida.

25 INSTITUTE OF INTERNAL AUDITORS (2003) http://www.theiia.org/ecm. (Accessed 15 January 2003).

26 INSTITUTE OF INTERNAL AUDITORS (2005) http://www.theiia.org/index.cfm? doc_id=270. (Accessed 20 April 2005).

27 IFAC (INTERNATIONAL FEDERATION OF ACCOUNTANTS) (2004) Enterprise Governance: Getting the Balance Right, Professional Accountants in Business Committee of the International Federation of Accountants, http://www.ifac.org. (Accessed 19 September 2005).

28 ISA, M. (2002) "Eskom: 9 per cent of staff HIV positive", News 24. Reuters. http:// www.news24.com. (Accessed 7 June 2002). 
29 JANSE VAN RENSBURG, E. (2000) "The origin of HIV", South African Journal of Science, 96: 267-269.

30 KING COMMITTEE ON CORPORATE GOVERNANCE (2002) King Report on Corporate Governance for South Africa, Institute of Directors: Johannesburg.

31 KINNEY, W.R. (2003) Research Opportunities in Internal Auditing - AUDITING risk Assessment and Risk Management Processes, Institute of Internal Auditors Research Foundation: Altamonte Springs, Florida.

32 KROGSTAD, J.L.; RIDLEY, A.J. \& RITTENBERG, L.E. (1999) "Where we're going?" Internal Auditor, 56(5): 27-33.

33 MARKS, N. (2001) "The new age of internal auditing”, Internal Auditor, 58(6): 44-49.

34 MAUTZ, R.K. \& SHARAF, H.A. (1984) The Philosophy of Auditing, American Accounting Association: Madison.

35 MCINTOSH, E.R. (1999) Competency Framework for Internal Auditing: An Overview, Institute of Internal Auditors Research Foundation: Altamonte Springs, Florida.

36 MICCOLIS, J.A., HIVELY, K. \& MERKLEY, B.W. (2001) Enterprise Risk Management: Trends and Emerging Practices, Institute of Internal Auditors Research Foundation: Altamonte Springs, Florida.

37 MOELLER, R.R. (2005) Brink's Modern Internal Auditing (6 ${ }^{\text {th }}$ ed.) Wiley: Hoboken, New Jersey.

38 NAGY, A.L. \& CENKER, W.J. (2002) "An assessment of the newly defined internal audit function”, Managerial Auditing Journal, 17(3): 130-137.

39 OPPENHEIM, A.N. (1992) Questionnaire Design and Attitude Management, Heinemann: London.

40 PICKFORD, J. (2001) Mastering Risk Volume 1: Concepts (1 ${ }^{\text {st }}$ ed.) Pearson Education: London.

41 PRICEWATERHOUSECOOPERS (1999) Enhancing Shareholder Wealth by Better Managing Business Risk, Financial and Management Accounting Committee, International Federation of Accountants: NewYork City, New York.

42 PRICEWATERHOUSECOOPERS (2000) Corporate Governance and the Board - What Works Best, The Institute of Internal Auditors Research Foundation: Altamonte Springs, Florida.
43 RAMAMOORTI, S. (2003) Research Opportunities in Internal Auditing - Internal Auditing: History, Evolution and Prospects, Institute of Internal Auditors Research Foundation: Altamonte Springs, Florida.

44 RANDALL, C. (2002) "Impacts and responses of industries, workplaces and sectors of the South African economy", In HIVIAIDS, Economics and Governance in South Africa: Key Issues in Understanding Response, USAID: Washington.

45 SABCOHA. (2002) South African Business Coalition on HIV and AIDS - a South African Business Response to the HIV and AIDS Epidemic: February, Bureau for Economic Research: Johannesburg.

46 SAWYER, L.B.; DITTENHOFER, M.A. \& SCHEINER. J.H. (1996) Sawyer's Internal Auditing (4 $4^{\text {th }}$ ed.) The Institute of Internal Auditors: Altamonte Springs, Florida.

47 SKIPPER, H.D. (1998) International Risk and Insurance ( $1^{\text {st }}$ ed.) McGraw-Hill/Irwin: London.

48 SPIRA, L.F. \& PAGE, M. (2003) "Risk management: the reinvention of internal control and the changing role of internal audit", Accounting, Auditing \& Accountability Journal, 16(4): 640-661.

49 STEINBERG, R.M. \& POJUNIS, D. (2000) "Corporate governance: the new frontier", Internal Auditor, 57(6): 34-39.

50 STODDARD, E. (2002) "Experts: AIDS digging hole in SAB", News 24. Reuters. http:// www.news24.co.za. (Accessed 12 April 2002).

51 TRICKER, R.I. (1984) Corporate Governance: History of Management Thought Series, Ashcroft Publishing: Aldershot.

52 UNAIDS (2000) The Business Response to HIV/ AIDS: Impact and Lessons Learned. http:// data.unaids.org/Publications/IRC-pub05/JC445BusinessResp_en.pdf.(Accessed 24 July 2003).

53 UNAIDS/WHO (2003) AIDS Epidemic Update, Joint United Nations Programme on HIV/AIDS and World Health Organisation, http:// www.unaids.com. (Accessed 12 December 2003).

54 UNAIDS/WHO (2004) AIDS Epidemic Update, Joint United Nations Programme on HIV/AIDS and World Health Organisation. http:// www.unaids. org/wad2004/EPIupdate. (Accessed 17 December 2004).

55 VALSAMAKIS, A.C.; VIVIAN, R.W. \& DU TOIT, G.S. (2000) Risk Management (2 $2^{\text {nd }}$ ed.) Heinemann Higher and Further Education: Johannesburg. 
56 WALKER, P.L.; SHENKIR, W.G. \& BARTON, T.L. (2002) Enterprise Risk Management: Pulling it all Together, Institute of Internal Auditors Research Foundation: Altamonte Springs: Florida
57 WARD, D.E. (1999) The AmFAR Handbook: The Complete Guide to Understanding HIVI $A I D S$, Norton: New York.

58 ZIKMUND, W.G. (2000) Business Research Methods ( $6^{\text {th }}$ ed.) Harcourt College Publishers: London. 